Diabetologia 8, 260-266 (1972)

(C) by Springer-Verlag 1972

\title{
Determination of Total Serum Insulin (IRI) in Insulin-treated Diabetic Patients
}

\author{
Lise G. HedING \\ Novo Research Institute, Copenhagen, Denmark
}

Received: December 28, 1971, accepted: March 20, 1972

\begin{abstract}
Summary. A routine method is described for the determination of total IRI (immunoreactive insulin) in insulintreated diabetics. The method involves an easy acid ethanol extraction, whereby antibody-bound IRI is dissociated and separated, together with the "free" IRI from the serum proteins and the antibodies. The recovery of IRI in this procedure is about $80 \%$. After the separation, the isolated total IRI is measured in an immunoassay, using ethanol for the separation of free and antibody bound ${ }^{125}$ I-insulin. In 169 diabetic patients treated with insulin in doses of from 6 to 120 units/day, the fasting serum total IRI was between 6 and $4374 \mu \mathrm{U} / \mathrm{ml}$, with a mean of $392 \mu \mathrm{U} / \mathrm{ml}$. During treatment with insulin, the level of total IRI increased from normal values, registered during the first two months, to a higher level which became stable after about 5 months of treatment. The increase in IRI occurred simultaneously with the formation of antibodies. Insulin-resistant patients showed very high IRI levels.
\end{abstract}

Determination de l'insuline totale chez les diabétiques traités a l'insuline

Résumé. On décrit une méthode de routine pour le dosage de l'IRI (insuline immunoréactive) totale chez les diabétiques traités par l'insuline. La méthode comprend une extraction à l'acide-éthanol, très simple, pendant laquelle l'TRI liée aux anticorps est dissociée et séparée ainsi que l'IRI 》libre des protéines sériques, anticorps compris. La récupération de l'IRI par cette méthode est aux environs de $80 \%$. Après la séparation, l'IRI totale isolée est mesurée par un dosage immunologique qui se sert de l'éthanol afin de séparer l' $1^{125}$-insuline libre de celle liée aux anticorps. Chez 169 malades diabétiques traités par l'insuline à des doses allant de 6 à 120 unités par jour, l'IRI totale sérique à jeun était de 6 à $4374 \mu \mathrm{U} / \mathrm{ml}$, avec une moyenne de $392 \mu \mathrm{U} / \mathrm{ml}$. Pendant le traitement par l'insuline le taux de l'IRI totale est passé des niveaux normanx, enregistrés pendant les deux premiers mois, à des niveaux plus éleévs qui se stabilisent 5 mois environ apres le début du traitement. L'augmentation de l'TRT coïncide avec la formation d'anticorps. Les malades insulino-résistants présentent des valeurs très hautes d'TRI.

Bestimmung des Gesamtserum-Insulins (IRI) bei insulinbehandelten Diabetikern

Zusammenfassung. Für die Bestimmung des GesamtIRI (immunoreaktiven Insulins) bei Diabetikern, die mit Insulin behandelt wurden, wird eine Routinemethode beschrieben. Die Methode schließt eine einfache SäureÄthanol-Extraktion ein, wobei das antikörpergebundene IRI dissoziiert und zusammen mit dem ,freien" IRI von den Serumproteinen, einschließlich den Antikörpern, getrennt wird. Bei diesem Verfahren werden etwa $80 \%$ des IRI wiedergefunden. Nach der Trennung wird das isolierte Gesamt-IRI immunologisch gemessen. Für die Trennung des freien von dem an Antikörper gebundenen ${ }^{125}$ I-Insulin wird Äthanol verwendet. Bei 169 Diabetikern, die mit 6 bis $120 \mathrm{E}$ Insulin/Tag behandelt wurden, lag das Nüchternserum-Gesamt-IRI zwischen 6 und $4374 \mu \mathrm{E} / \mathrm{ml}$ (Mittelwert $392 \mu \mathrm{E} / \mathrm{ml}$ ). Im Laufe der Insulinbehandlung stieg das Gesamt-IRI von Normalwerten, die während der ersten 2 Monate registriert wurden, auf ein höheres Niveau an, das sich nach etwa 5 Monaten Behandlungsdauer stabilisierte. Der Anstieg des IRI erfolgte gleichzeitig mit der Bildung von Antikörpern. Bei insulinresistenten Patienten ergaben sich sehr hohe IRI-Konzentrationen.

Key words: Insulin, radioimmunoassay, total IRI in insulin-treated diabetics, acid ethanol extraction of insulin.

\section{Introduction}

Yalow and Berson (1960) were the first to develop and describe the insulin radioimmunoassay, and since then this assay has been widely used, either in its original form or in a form modified, e.g., with respect to the tracer and/or the separation technique, in order to meet the requirements of a routine method. As a result of the availability of these routine methods, an enormous amount of information has been collected over the past 11 years about the concentration of immunoreactive insulin (IRI) in serum from normal persons and untreated diabetic patients. However, information about IRI levels in insulin-treated patients is wanting.

When diabetic patients are treated with commercial insulin preparations, nearly all of them develop insulin antibodies (Berson and Yalow, 1964) after a few months of treatment. The serum from these patients then contains a mixture of "free" insulin, antibody-bound insulin and free antibodies. Due to the presence of antibodies, it is not possible to determine the total amount of IRI by a direct immunoassay such as those used for the sera from normals and diabetics not treated with insulin. The antibodies must be removed from the diabetic serum before an IRI determination can be performed.

Grodsky (1965) extracted insulin from the sera of two resistant patients and found values as high as $12 \mathrm{mU}$ of total insulin per $\mathrm{ml}$ of serum. Heding and Vølund (1967) and Heding (1969) deseribed a routine method of acid extraction for the determination of total insulin in insulin-treated patients. In a series of insulin-treated diabetic patients (10 to 120 i. U. a day) 
the IRI values were found to range between 0 and $3000 \mu \mathrm{U} / \mathrm{ml}$. Ohneda et al. (1970) described a plasma extraction method which abolished a non-specific inhibitor of the double-antibody method. Furthermore, the extraction removed the antibodies present in the serum, making it possible to determine IRI in sera from insulin-treated diabetics. Determination of IRI performed in eight sera gave values of from 10 to $390 \mu \mathrm{U} / \mathrm{ml}$. Pearson and Martin (1970) developed gel filtration, on Sephadex G-50, of plasma from diabetic patients after dissociation of the insulin-antibody complex at low pH. Using this method, the authors found between 700 and $6000 \mu \mathrm{U}$ IRI per ml of plasma of six fasting, insulin-treated diabetic patients.

This paper describes a routine method for the determination of total IRI in insulin-treated patients, and consists of two parts: 1 . insulin radioimmunoassay and 2. determination of total IRI in serum from insulin-treated persons.

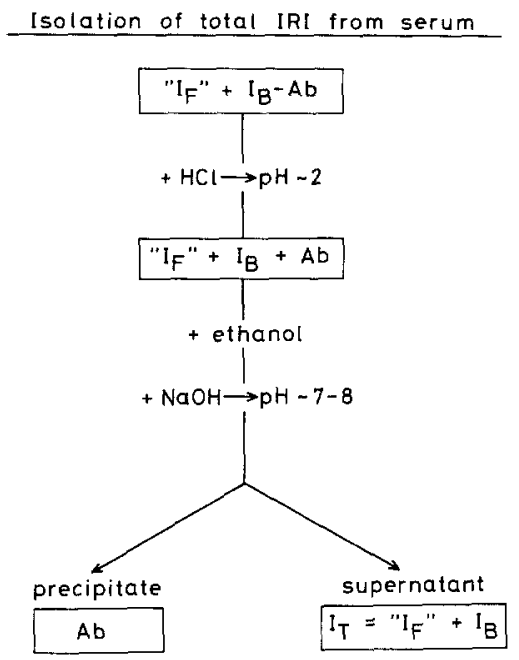

Fig. 1

1. Insulin radioimmunoassay. The general principles of radioimmunoassay are well known. One of the most critical steps in this assay is the separation of free and antibody-bound ${ }^{125} \mathrm{I}$-insulin. A number of techniques are available today (Kirkham and Hunter, 1971).

In the ethanol method, the free and the antibodybound insulin are separated by addition of $96 \%$ ethanol to give a final concentration of $79 \%$. This method was dereloped (Heding, 1966) as a substitute for the paper chromatographic method and the double. antibody method, to avoid the time consumed by the former and the sources of error of the latter.

2. Determination of total IRI in serum of insulintreated persons. The principle of this method (Heding, $1967,1969)$ is shown in Fig. 1. The serum sample contains free IRI, antibody-bound IRI and a surplus of antibodies. The $\mathrm{pH}$ is adjusted to approximately 2 with $\mathrm{HCl}$; at this low $\mathrm{pH}$ the insulin-antibody complex dissociates immediately into free insulin and antibody. Ethanol is then added, and due to the low $\mathrm{pH}$ no precipitation of the serum proteins will take place until $\mathrm{NaOH}$ is added to bring the $\mathrm{pH}$ close to 7 . The ethanol concentration of this neutral mixture is approximately $75 \%$, at which level insulin does not react with antibody. The insulin remains in the supernatant and is separated from the precipitated antibodies and other serum proteins by centrifugation. The supernatant is evaporated in an exsiccator in vacuum, and the residue is dissolved in buffer and immunoassayed.

\section{Materials and Methods}

Monocomponent-insulins of human, porcine and bovine origin, with biological activities of $25.4,27.2$ and 25.7 i. U./mg, respectively, (supplied by the NOVO Insulin Laboratory), were used as standards.

${ }^{125} \mathrm{I}$-pork insulin was used as tracer. It was prepared by iodinating monocomponent-pork insulin with ${ }^{125} \mathrm{I}$ according to Jørgensen and Binder (1966). Its specific activity was approximately $30 \mathrm{mCi} / \mathrm{mg}$. ${ }^{125} \mathrm{I}$-insulin and anti-insulin sera were diluted in phosphate buffer $(0.04 \mathrm{M}$, $\mathrm{pH}$ 7.4) containing human albumin (Behringwerke) (1 g/l) and thiomersal $(0.2 \mathrm{~g} / \mathrm{I})$ (subsequently referred to as FAM). All standards and samples were dissolved and diluted in phosphate buffer $(0.04 \mathrm{M}, \mathrm{pH}$ 7.4) containing $\mathrm{NaCl}(6 \mathrm{~g} / \mathrm{l})$, human albumin $(60 \mathrm{~g} / \mathrm{l})$ and thiomersal $(1 \mathrm{~g} / \mathrm{l})$ (subsequently referred to as NaFAM).

Insulin antibodies were raised by injecting guinea pigs (weighing $300-400 \mathrm{~g}$ ) with $0.5 \mathrm{ml}$ of an emulsion of $3.75 \mathrm{ml}$ sterile water and $6.25 \mathrm{ml}$ of Zine Protamine Insulin (NOVO, pork insulin, $80 \mathrm{i} . \mathrm{U} . / \mathrm{ml}$ ) and $10 \mathrm{ml}$ of Freund's adjuvant, corresponding to a dose of 12.5 units of insulin; this dose was subsequently increased to 25 units. The guinea pigs were allowed $10 \%$ glucose water ad libitum after the injections.

The radioimmunoassay procedure was as follows: to triplicates of $100 \mu \mathrm{l}$ of standard solutions (containing from 10 to $100 \mu \mathrm{U}$ of insulin $/ \mathrm{ml}$ ) or samples was added $100 \mu \mathrm{l}$ of anti-insulin guinea-pig serum diluted $1: 35000$. After $20 \mathrm{~h}$ of incubation at $4^{\circ} \mathrm{C}, 100 \mu \mathrm{l}$ of ${ }^{125} \mathrm{I}$-insulin $(200 \mu \mathrm{U} / \mathrm{ml})$ was added at $4^{\circ} \mathrm{C}$, and after another incubation period at $4^{\circ} \mathrm{C}(4-20 \mathrm{~h}), 1.6 \mathrm{ml}$ of ethanol was added in order to separate the free and the antibody-bound insulin. After mixing and centrifugation for $10 \mathrm{~min}$ at $2500 \mathrm{rpm}$, the supernatant containing the free ${ }^{125} \mathrm{I}$-insulin was decanted into disposable plastic tubes (diameter: $10 \mathrm{~mm}$, height: $75 \mathrm{~mm}$, NUNC, Roskilde, Denmark), the tubes were stoppered with plastic stoppers, and the radioactivity counted.

Blood was drawn from the antecubital vein into glass tubes and allowed to clot for one hour at room temperature before centrifugation. The serum was pipetted into plastic tubes and stored at $-18^{\circ} \mathrm{C}$ until used.

Determination of the total amount of IRI was done as follows: to duplicates of $500 \mu \mathrm{l}$ of serum was added $100 \mu \mathrm{l}$ of $1 \mathrm{~N} \mathrm{HCl}$ to give a $\mathrm{pH}$ of approximately 2.5. The tubes were shaken and incubated at room temperature for $10 \mathrm{~min}$, whereupon $2.5 \mathrm{ml}$ of $95 \%$ ethanol was added and the contents mixed by vigorously inverting the tubes. Due to the low $\mathrm{pH}$, the plasma proteins did not precipitate. $100 \mu \mathrm{l}$ of $1 \mathrm{~N} \mathrm{NaOH}$ was then added, and again, the mixture was shaken vigorously. A heavy protein precipitate was formed. The precipitate was separated by centrifugation for $10 \mathrm{~min}$ at about $2000 \mathrm{G}$, and the supernatant, containing the insulin, was transferred to a small bottle and evaporated to dryness in a dessiccator 
under a pressure of $10 \mathrm{~mm} \mathrm{Hg}$ overnight. One hundred samples could easily be handled simultaneously. The dry residue was dissolved in $1 \mathrm{ml}$ of NaFAM buffer and immunoassayed.

\section{Results}

\section{Insulin radioimmunoassay}

\section{Concentration of ethanol, salt, albumin}

Two requirements should be fulfilled in connection with the use of ethanol for the separation of free and antibody-bound ${ }^{125} \mathrm{I}$-insulin, viz.: 1. complete precipitation of all the ${ }^{{ }^{125}} \mathrm{I}$-insulin in an incubation medium containing insulin antibodies in surplus, and 2. no precipitation of ${ }^{125}$ I-insulin in solutions containing no antibodies. As previously shown (Heding, 1966), these requirements are fulfilled by adding $1.6 \mathrm{ml}$ of $96 \%$ ethanol to $0.3 \mathrm{ml}$ of an incubation mixture to give a final ethanol concentration of approximately $79 \%$. Complete immunoassays (including standard curves and serum samples) were run simultaneously using double-antibody, paper chromatographic or ethanol separation techniques. No significant differences could be found in the per cent ${ }^{125} \mathrm{I}$-insulin bound to antibodies either in the standards or in the samples.

A minimum concentration of $0.02 \mathrm{M} \mathrm{Cl}^{-}$(or other monovalent anions) was found necessary to ensure complete precipitation of the insulin-antibody complex; furthermore, the insulin-antibody complex was shown to be stable in $79 \%$ ethanol for several hours.

The protein concentration influences the coprecipitation of the ${ }^{125} \mathrm{I}$-insulin. Coprecipitation of free ${ }^{125}$ I-insulin in the presence of different serum samples and $6 \%$ albumin containing buffer was between $4.6 \%$ and $5.2 \%$. It is important that the protein concentration should be the same in all incubation mixtures, and a final concentration of $2 \%$ has been used throughout.

At temperatures below $10^{\circ} \mathrm{C}$, the coprecipitation increases, and the temperature in the final mixture should therefore be above $10^{\circ} \mathrm{C}$ (e.g., ethanol at room temperature).

Adsorption of ${ }^{125}$ I-insulin to different types of tubes, concentration of ${ }^{125} I$-insulin in foam. It is a well-known phenomenon that insulin in low concentration (ng range) is adsorbed to the surface of glass-ware unless other substances are present - preferably proteins. Probably, these proteins, e.g. albumin, compete with the insulin for the binding site on the glass-ware, and if albumin is present in great excess, the loss of insulin due to adsorption will be minimal. However, the degree of insulin adsorption depends not only on the amount of protein present but also on the type of glass or plastic-ware used. The adsorption of 125I-labelled ox proinsulin to four different types of glass and plastic tubes was examined. It was found that the plastic tube absorbed $2 \%$ of the ${ }^{125}$ I-labelled ox proinsulin, whereas the glass tubes adsorbed between 13 and $37 \%$ of the tracer at $0.1 \%$ albumin concentration.
The adsorption was diminished by addition of, e.g., serum or by increasing the concentration of albumin. The adsorption to glass-ware was also demonstrated using ${ }^{125} \mathrm{~T}$-insulin. It is obvious that the type of tube used for immunoassay should be carefully selected. The same holds true for the glass-ware that is used to store and prepare the ${ }^{125} \mathrm{I}$-insulin solutions.

Solutions of ${ }^{125}$ I-insulin in FAM containing $0.1 \%$ albumin foam readily upon shaking. The concentration of ${ }^{125}$ I-insulin is higher in the foam than in the solution. This circumstance may induce serious errors. A frozen solution of ${ }^{125} \mathrm{I}$-insulin was shaken during thawing and $100 \mu \mathrm{l}$ volumes were pipetted into tubes and counted. The first 90 tubes contained the same amount of 125I-insulin. In the subsequent tubes the radioactivity increased, with the final $\mathbf{4}-\mathbf{5}$ tubes exhibiting very high concentrations of ${ }^{125} \mathrm{I}$-insulin. Obviously, the foam with its higher concentration of ${ }^{125}$ I-insulin had gradually settled thereby increasing the concentration of ${ }^{125}$ I-insulin in the solution.

\section{Degradation of insulin by different typés of albumin}

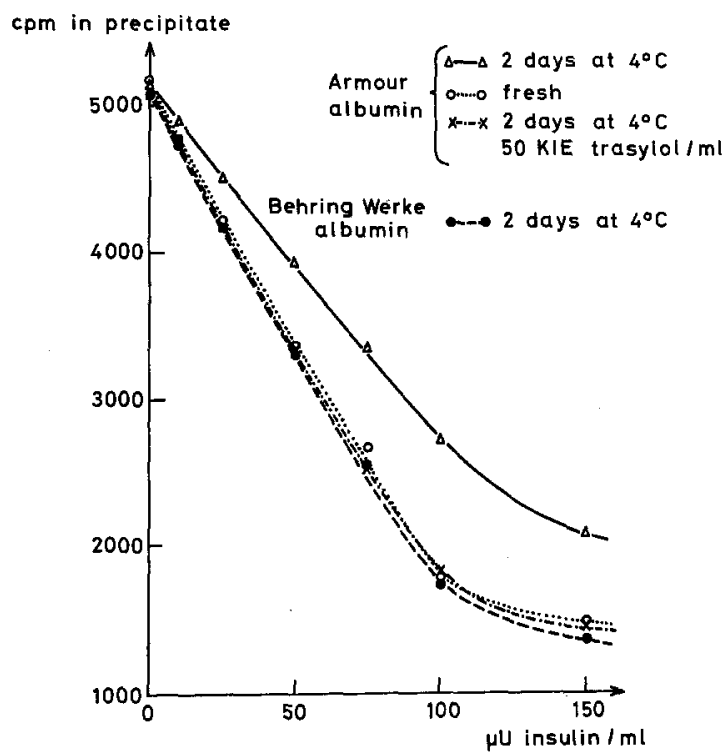

Fig. 2

Quality of albumin and ${ }^{125}$ I-insulin; degradation of insulin by serum. As mentioned before, albumin is added to all buffer solutions in order to prevent adsorption of insulin to glass-ware and to attain the same protein concentration in serum and standards. Many publications mention using bovine albumin fraction $\mathrm{V}$ (Armour) for this purpose. It was found, however, that this albumin contained enzymes capable of degrading insulin. The problem is illustrated in Fig. 2. A series of insulin standard solutions was prepared with bovine albumin made by Armour, and another one with human albumin made by Behringwerke. It was found that the insulin solution prepared with bovine albumin retained only about $65 \%$ of its original content of 
insulin after 2 days of storage at $4^{\circ} \mathrm{C}$. The reason was, no doubt, enzymatic degradation (and not the binding of insulin to albumin) because this degradation could be prevented with trasylol (a proteinase inhibitor).

A common "must" in all immunoassays is the use of a high-quality tracer. The significance of this requirement varies with the different methods of separation. Table 1 shows some results obtained with two

Table 1. Different qualities of ${ }^{125}$ I-insulin, effect of binding to antibody and coprecipitation

\begin{tabular}{|c|c|c|}
\hline \multirow[t]{2}{*}{ Incubation mixture } & \multicolumn{2}{|c|}{$\%$ precipitated } \\
\hline & $\begin{array}{l}{ }^{125} \mathrm{I} \text {-insulin }{ }^{\mathrm{a}} \\
\text { K. Jørgensen }\end{array}$ & $\begin{array}{l}{ }^{125} I_{-} \text {-insulina } \\
\text { commercial }\end{array}$ \\
\hline $\begin{array}{l}\text { surplus of antibody } \\
{ }_{125} \text { I-insulin }\end{array}$ & 97.6 & 84 \\
\hline $\begin{array}{l}\mathrm{N} \text {-serum I } \\
\text { i25I-insulin }\end{array}$ & 4.3 & 25 \\
\hline $\begin{array}{l}\text { N-serum II } \\
\text { 125I-insulin }\end{array}$ & 4.5 & 23 \\
\hline 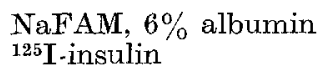 & 5.0 & 23 \\
\hline
\end{tabular}

a the concentration of ${ }^{125} \mathrm{I}$-insulin in both preparations was approx. $220 \mu \mathrm{U} / \mathrm{ml}$.

different ${ }^{125}$ I-insulin preparations: one of them was labelled by the method of K. Jørgensen (Jørgensen and Binder, 1966), the other one was a commercially available preparation. It is obvious that a part of the radioactivity in the commercial preparation was not bound to insulin since only $84 \%$ could be "bound" to insulin antibodies in surplus, and since more than $20 \%$ was precipitated in the absence of antibody.

The degradation of insulin in plasma and serum has been discussed in numerous papers. No detectable degradation occurs in serum stored at $-18^{\circ} \mathrm{C}$; the problem first arises when serum is handled at temperatures above $0^{\circ} \mathrm{C}$. No difference could be shown in the IRI content of six serum samples obtained from a normal person during an oral glucose tolerance test after $4 \mathrm{~h}$ of storage at $-18^{\circ} \mathrm{C}, 4^{\circ} \mathrm{C}$ and $30^{\circ} \mathrm{C}$ (TRI values between 17 and $68 \mu \mathrm{U} / \mathrm{ml}$ ).

Reproducibility of standard curves, standard deviation of triplicates, day-to-day variation in serum IRI determinations, normal IRI values. Fig. 3 shows the reproducibility of 7 different standard curves obtained over a period of three weeks. The day-to-day variation is small, but it is advisable always to set up a standard curve together with the samples to be assayed.

The counts from the immunoassay were recorded direct on a punch tape, which was transferred to an IBM 1130 computer and processed according to a program developed by Vølund (1972). The results were written as mean values with the $95 \%$ interval. In the range of $0-80 \mu \mathrm{U} / \mathrm{ml}$, the $95 \%$ interval of 59 determinations (2 experiments) was $2.83 \mu \mathrm{U} / \mathrm{ml}$ \pm 0.82 (mean $\neq$ s.d.). The $95 \%$ interval was the same throughout the entire range, meaning that the most accurate determinations are obtained using the upper part of the standard curve. Two normal sera were assayed in 10 different immunoassays, giving the following results: $39.6 \pm 3.0$ and $81.1 \pm 4.8 \mu \mathrm{U} / \mathrm{ml}$ (mean \pm s.d.). Dilution of the serum samples gave the expected values, and recovery of added insulin was practically $100 \%$. Twenty-four normal fasting persons showed IRI values between 0 and $\mathbf{1 6} \mu \mathrm{U} / \mathrm{ml}$ (mean $7.2 \mu \mathrm{U} / \mathrm{ml}$ ). One hour after $1.75 \mathrm{~g}$ of glucose $/ \mathrm{kg}$, their IRI values were between 30 and $150 \mu \mathrm{U} / \mathrm{ml}$ (mean $69.6 \mu \mathrm{U} / \mathrm{ml})$.

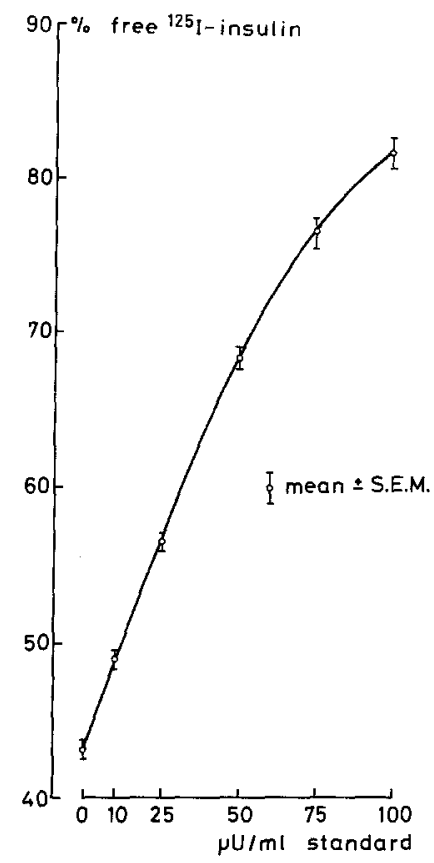

Fig. 3

\section{Determination of total IRI in serum from insulin- treated persons}

Dissociation of the insulin-antibody complex. A prerequisite of a reliable determination of the total IRI content in antibody-containing diabetic sera is a complete dissociation of the insulin-antibody complex and subsequent removal of the antibodies. Fig. 4 shows the dissociation of a ${ }^{125} \mathrm{I}$-insulin-antibody complex after addition of $\mathrm{HCl}$ to a $\mathrm{pH}$ of approximately 2.5. Serum from an insulin treated diabetic patient was incubated with ${ }^{125} \mathrm{I}$-insulin for $24 \mathrm{~h}$ at $4^{\circ} \mathrm{C}$, after which $67 \%$ of the labelled insulin was bound. $\mathrm{HCl}$ was added to give a $\mathrm{pH}$ of approximately 2.5. The amount of bound ${ }^{125} \mathrm{~T}$-insulin was determined at various intervals after the addition of $\mathrm{HCl}$ by adding ethanol. It was found that the dissociation of the ${ }^{125}$ I-insulin-antibody complex was immediate and complete. Only $3.5 \%$ of the ${ }^{125}$ I-insulin was precipitated together with the proteins. 
Recovery; serial dilutions of the extracted insulin. The recovery of insulin in the extraction procedure has been determined using the following three approaches:

1. addition of ${ }^{125}$ I-insulin to normal and diabetic sera

2. use of normal sera with a known insulin concentration

3. use of normal sera with a known insulin concentration added to guinea-pig anti-insulin serum (AIS).

The recovery of ${ }^{125} \mathrm{I}$-pork insulin added to diabetic sera varied from 79 to $84 \%$ in 12 sera. The recovery of insulin from standard solutions containing from 25 to

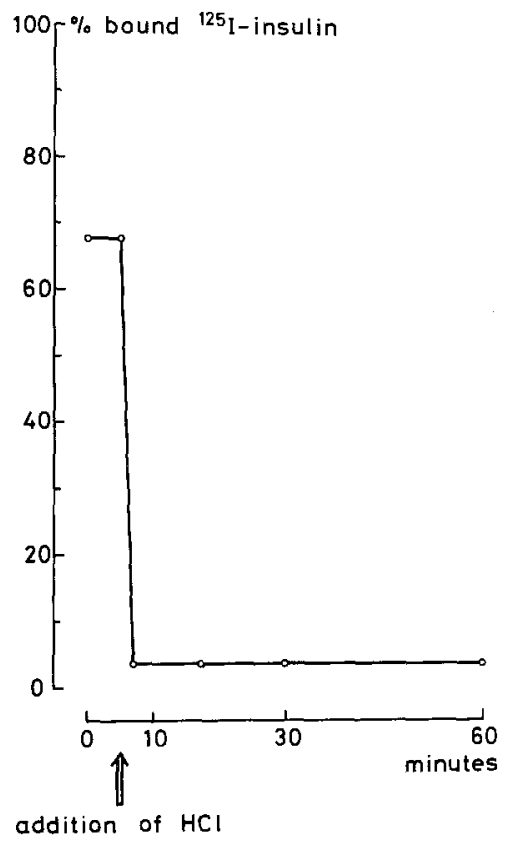

Fig. 4

$150 \mu \mathrm{U} / \mathrm{ml}$ was from 72 to $88 \%$ (mean $77 \%$ ). The recovery of insulin from a normal serum with and without addition of a surplus of AIS was about $75 \%$ in both cases.

The day-to-day variation in extraction yield was determined in regard to 3 normal sera with different levels of insulin. The sera contained 150, 90 and $41 \mu \mathrm{U} / \mathrm{ml}$ and the mean recovery \pm s.d. was $76 \pm 2 \%$ (9 extractions), $76 \pm 5 \%$ (14 extractions) and $68 \pm$ $10 \%$, respectively. As expected, the recovery was slightly lower and exhibited more variation at low insulin concentrations. Twenty-eight triplicate extractions carried out the same day, with the extracts assayed simultaneously, showed a mean s.d. of $2.6 \%$.

Insulin extracted from human sera (normal as well as that of insulin-treated diabetics) was dissolved in buffer and serial dilutions were prepared and immunoassayed. A linear dilution curve was obtained in all cases. Three examples are given in Fig. 5. The extracts were also checked for their contents of insulin antibodies and they were found not to contain any.

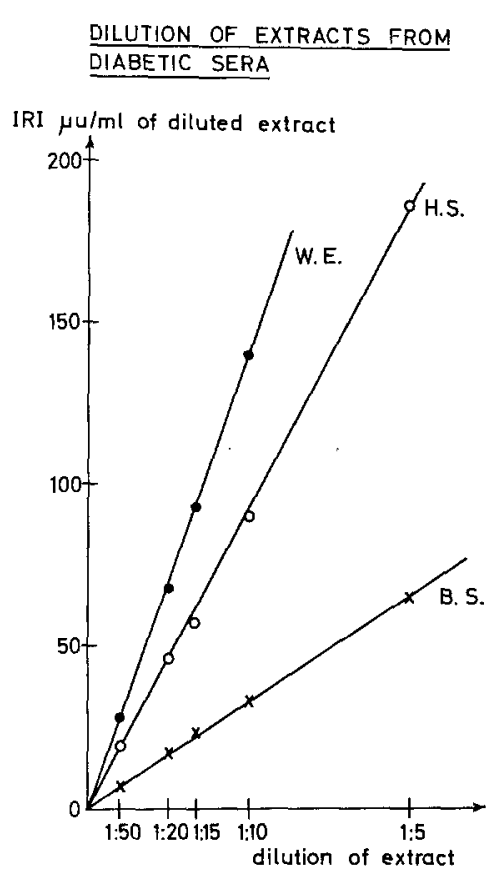

Fig. 5

Table 2. Total insulin in insulin-treated diabetic patients

\begin{tabular}{lrrrr}
\hline $\begin{array}{l}\text { Daily insulin } \\
\text { dose } \\
\text { i.U. }\end{array}$ & $\begin{array}{l}\text { No. of } \\
\text { patients }\end{array}$ & mean & $\begin{array}{l}\text { Total IRI } \\
\text { rU/ml } \\
\text { range }\end{array}$ & s.e.m. \\
\hline $6-20$ & 20 & 252 & $6-1192$ & 75 \\
$21-40$ & 110 & 341 & $8-2060$ & 49 \\
$41-60$ & 35 & 543 & $32-4347$ & 147 \\
$61-80$ & 3 & 492 & $48-1250$ & 380 \\
$>80$ & 1 & 3000 & - & - \\
\hline
\end{tabular}

Table 3. Determination of total fasting IRI in two patients before and after treatment with insulin

\begin{tabular}{|c|c|c|c|}
\hline Patient & Date & Total IRI & $\begin{array}{l}\text { Daily insulin } \\
\text { dose }\end{array}$ \\
\hline H.B. & $\begin{array}{rr}16 . & 6.67 \\
8 . & 8.67 \\
25 . & 8.67 \\
25 . & 9.67 \\
11 . & 12.67 \\
19 . & 12.67 \\
11 . & 3.68 \\
22 . & 3.68\end{array}$ & $\begin{array}{r}24 \\
22 \\
13 \\
178 \\
2221 \\
2172 \\
1895 \\
1815\end{array}$ & $\begin{array}{l}0 \\
8 \text { i.U. Lente } \\
8 \text { i.U. Lente } \\
14 \text { i.U. Lente } \\
20 \text { i.U. Lente } \\
28 \text { i. U. Lente } \\
36 \text { i.U. Lente } \\
40 \text { i. U. Lente }\end{array}$ \\
\hline E.M. & $\begin{array}{r}20 . \quad 7.67 \\
31 . \quad 8.67 \\
6.10 .67 \\
1.12 .67 \\
15 . \quad 3.68\end{array}$ & $\begin{array}{r}14 \\
34 \\
109 \\
272 \\
270\end{array}$ & $\begin{array}{l}0 \\
12 \text { i.U. Lente } \\
10 \text { i. U. Lente } \\
10 \text { i. U. Lente } \\
22 \text { i. U. Lente }\end{array}$ \\
\hline
\end{tabular}

Total IRI in insulin-treated patients. Table 2 shows the results of total-IRI determinations in sera from 169 insulin-treated fasting diabetic patients. The serum was drawn $14-24 \mathrm{~h}$ after the last insulin injection. All patients had been treated with inșulin for 
more than six months. The majority, by far, had elevated total IRI levels as compared to normals and untreated patients. Two examples of the variation in fasting total IRI in the course of treatment are shown in Table 3. A marked increase in total IRI was observed after 2-3 months of treatment.

Table 4. Variation in total fasting IRI in diabetics who had been treated with insulin for several years

\begin{tabular}{|c|c|c|c|c|}
\hline Patient & $\begin{array}{l}\text { Treat- } \\
\text { ment } \\
\text { started }\end{array}$ & Date & $\begin{array}{l}\text { Total } \\
\text { IRI }\end{array}$ & $\begin{array}{l}\text { Daily insulin } \\
\text { dose } \\
\text { i. U. Lente }\end{array}$ \\
\hline \multirow[t]{6}{*}{ A.B.J. } & \multirow[t]{6}{*}{1951} & 1. 9.66 & 2625 & 44 \\
\hline & & 28. 4. 67 & 1915 & 50 \\
\hline & & 24. 8.67 & 2550 & 46 \\
\hline & & 24.11 .67 & 1540 & 46 \\
\hline & & 2. 2.68 & 1452 & 46 \\
\hline & & 3. 5.68 & 1500 & 一 \\
\hline \multirow[t]{3}{*}{ H.L.T. } & \multirow[t]{3}{*}{1945} & 18.11 .66 & 1128 & 48 \\
\hline & & 25.11 .66 & 1074 & 44 \\
\hline & & 2. 12.66 & 1120 & 42 \\
\hline \multirow[t]{3}{*}{ J.A.H. } & \multirow[t]{3}{*}{1936} & 7.10 .66 & 224 & 32 \\
\hline & & 14.10 .66 & 190 & 34 \\
\hline & & 21.10 .66 & 233 & 34 \\
\hline \multirow[t]{2}{*}{ A.H. } & \multirow[t]{2}{*}{1942} & $26 . \quad 9.66$ & 346 & 28 \\
\hline & & 7. 10.66 & 214 & 28 \\
\hline \multirow[t]{2}{*}{ H.S. } & \multirow[t]{2}{*}{1951} & 26.9 .66 & 2212 & 48 \\
\hline & & 15.10 .66 & 1700 & 48 \\
\hline \multirow[t]{2}{*}{ E. $W$. } & \multirow[t]{2}{*}{1964} & 24. 9.66 & 23 & 32 \\
\hline & & 26.9 .66 & 43 & 32 \\
\hline \multirow[t]{3}{*}{ J.H. } & \multirow[t]{3}{*}{1937} & 7. 10.66 & 280 & 36 \\
\hline & & 14.10 .66 & 380 & 36 \\
\hline & & 31.10 .66 & 352 & 36 \\
\hline \multirow[t]{2}{*}{ B. W. } & \multirow[t]{2}{*}{1940} & 7. 10.66 & 318 & 30 \\
\hline & & 14. 10.66 & 312 & 30 \\
\hline \multirow[t]{3}{*}{ F.M. } & \multirow[t]{3}{*}{1965} & 6.10 .66 & 54 & 24 \\
\hline & & 14.10 .66 & 94 & 24 \\
\hline & & 21.10 .66 & 61 & 24 \\
\hline \multirow[t]{2}{*}{ F.J. } & \multirow[t]{2}{*}{1950} & 5. 5. 67 & 35150 & 184 \\
\hline & & 16. 5.67 & 50700 & 240 \\
\hline
\end{tabular}

a serum from this resistant patient was obtained by courtesy of Dr. Hockaday, Oxford, England.

The variation in total IRI in patients who had been treated with insulin for several years is shown in Table 4. The level of total fasting IRI remained fairly stable from week to week.

The daily insulin injection(s) caused some variation in the level of total IRI, as shown in Fig. 6.

\section{Discussion}

1. Insulin radioimmunoassay. Each radioimmunoassay method has a number of sources of error, some of which are common to most methods, others being specific for a particular method.

The adsorption of ${ }^{125} \mathrm{I}$-insulin to plastic and glassware is probably of much greater consequence than one usually realizes. It has been generally accepted that the presence of $0.1 \%$ albumin effectively prevents this adsorption of ${ }^{125} \mathrm{I}$-insulin. However, this is not the case in every type of tube. The ability of ${ }^{125}$ I-insulin to concentrate in foam may completely invalidate the results.

Variation in the protein concentration will influence most of the separation techniques used in radioimmunoassay. Thus, the binding of free ${ }^{125}$ I-insulin to cellulose, ion-exchangers, charcoal and similar substances is diminished at higher albumin concentrations. When ethanol is used for the separation of free and bound ${ }^{125} \mathrm{I}-\mathrm{insulin}$, the coprecipitation of free ${ }^{125} \mathrm{I}$-insulin will increase at higher protein concentrations. It is therefore obvious that the protein concentration in the standards must be the same as in the test samples.

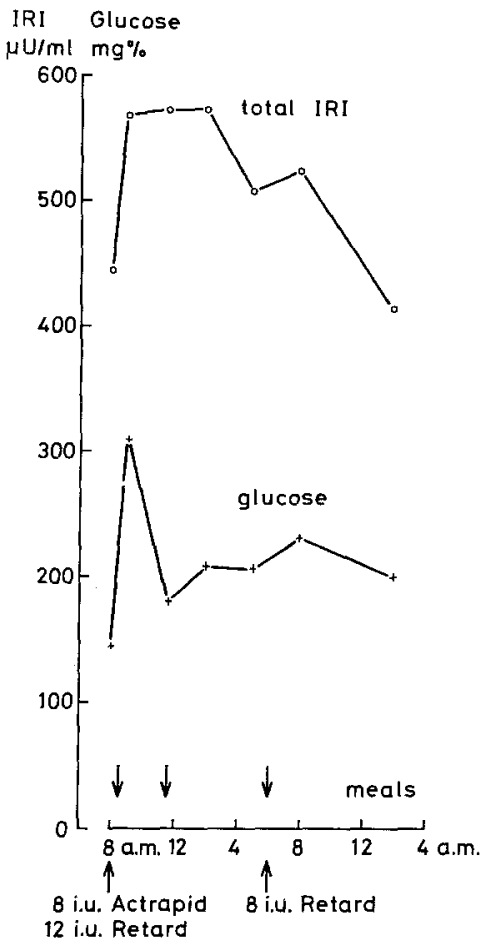

Fig. 6

Enzymatic degradation of insulin during incubation will, of course, give false values. The degree of degradation in human sera was found to be very low, but sera from other species exhibited a much more pronounced degradation of ${ }^{125} \mathrm{I}$-insulin. Some types of albumin contain enzymes that degrade the standard insulin (Fig. 4) and thereby reduce the stability of the standard solutions. When use was made of a pure albumin, solutions containing from 10 to $5000 \mu \mathrm{U}$ insulin $/ \mathrm{ml}$ were found to remain stable for more than a year at $-18^{\circ} \mathrm{C}$. Anti-insulin sera stored at $-18^{\circ} \mathrm{C}$ have been used since 1966 without our detecting any changes in their binding capacity.

The immunoassay method here described makes use of $96 \%$ ethanol for the separation of free and antibody-bound ${ }^{125}$ I-insulin. This method has several advantages: it is accurate, quick and easy to perform, and the $96 \%$ ethanol is an ordinary, inexpensive 
standard chemical. For optimal results a good ${ }^{125} \mathrm{I}$ insulin preparation is required, as shown in Table 1. Ethanol separation has yielded results identical with those of the chromatographic and double-antibody separation techniques.

2. Determination of total IRI in serum from insulintreated persons. The presence of antibodies and antibody-bound insulin in serum from insulin-treated persons necessitates carrying out an acid ethanol extraction to obtain an estimate of the total IRI. The method involves a complete dissociation of the insulinantibody complex, followed by a precipitation of the antibodies in ethanol at neutral $\mathrm{pH}$. This method offers several advantages as compared to separation by gel filtration described by Pearson and Martin $(\mathbf{1 9 7 0})$ - it is a routine method in which more than 50 samples can easily be handled simultaneously; the dry residue can be dissolved direct in the buffer used for immunoassay.

The results obtained with this method showed the following :

1. Total fasting IRI in a randomly selected diabetic population treated with insulin in doses of between 6 and 120 units/day varied from 6 to $4347 \mu \mathrm{U} / \mathrm{ml}$ (mean $392 \mu \mathrm{U} / \mathrm{ml}$ ), and by far the majority of the patients had substantially elevated IRI values when compared with normal subjects and diabeties not treated with insulin.

2. The total IRI increased during the period of treatment from the normal values of the first month or two to a higher level, which then became fairly stable after about 5 months of treatment (two examples are shown in Table 3). The increase in IRI was observed simultaneously with the formation of antibodies. If no antibodies were produced, for instance due to treatment with monocomponent-insulin (Schlichtkrull et al., 1971), the serum IRI stayed within normal limits.

3. The fasting total IRI in diabetic patients treated with insulin for over five months varied only a little from week to week. Even in those treated several months longer, the changes observed were minor (Tables 3 and 4). That is to say, each patient has his own total IRI level.

4. Insulin-resistant patients (defined as diabetics whose daily dose of insulin exceeds 100 units) had so far proved to have extraordinarily high levels of IRI (one such case is demonstrated in Table 4).

5. The daily insulin injection(s) caused variations in the IRI level (Fig. 6).

The composition of the total IRI is of great interest. Most of the IRI is, naturally, bound to antibodies and has hardly any biological effect in vivo or in vitro. Stout and Vallance-Owen (1969) put forward the hypothesis that hyperinsulinism plays a major role in the development of vascular disease. Stout (1970) showed that chickens treated with insulin for 19 weeks developed vascular lesions faster than untreated chickens. Thus, the high total serum IRI found in diabetics could be contributory to the development of vascular complications in diabetes.

Acknowledgements. I wish to thank Jørgen Schlichtkrull, D. Sc., for his interest, constructive criticism and valuable advice; Mrs. Ulla Dahl Larsen for preparing the excellent ${ }^{125}$ I-insulin; the staff of Hvidøre Diabetes Hospital for drawing most of the serum samples used in this study; Mrs. Majken Petri Petersen, Mrs. Connie Eriksen and Miss Lene Hansen for their excellent technical assistance; and Mrs. Birgit Jensen for drawing the curves.

\section{References}

Berson, S.A., Yalow, R.S.: The present status of insulin antagonists in plasma. Diabetes 13, 247-259 (1964).

Grodsky, G.M.: Production of auto-antibodies to insulin in man and rabbits. Diabetes 14, 396-403 (1965).

Heding, L.G.: A simplified insulin radioimmunoassay method, in "Labelled Proteins in Tracer Studies", Ed. L. Donato et al. Euratom, Brussels $345-350$ (1966).

- Nielsen, A. Vølund: Determination of free and antibody-bound IRI in serum from insulin-treated diabetic patients. Abst, in Exerpta Medica international congress series No. 140, Sixth Congress of the International Diabetes Federation, Stockholm, 1967.

- Determination of free and antibody-bound insulin in insulin-treated diabetic patients. Horm. Metab. Res. 1, $145-146$ (1969).

Jørgensen, K., Binder, C.: ${ }^{125} \mathrm{I}$-insulin as a tracer of insulin. in different chemical processes, in "Labelled Proteins in Tracer Studies", Ed. L. Donato et al. Euratom, Brussels, $329-333$ (1966).

Kirkham, K.E., Hunter, W.M.: Radioimmunoassay Methods, Churchill Livingstone, Edinburgh and London (1971).

Ohneda, A., Toyota, T., Sato, S., Yamagata, S.: Extraction of plasma insulin in radioimmunoassay for removal of nonspecific inhibitor and of circulating insulin antibody. Tôhoku J. exp. Med. 100, 75-84 (1970).

Pearson, M.J., Martin, F.I.R.: The separation of total plasma insulin from binding proteins using gel filtration: its application to the measurement of rate of insulin disappearance. Diabetologia 6, 581-585 (1970).

Schlichtkrull, J., Heding, L.G., Christiansen, Aa.H., Vølund, Aa.: Immunological aspects of insulin therapy. Paper presented at the VIIth Acta endocrinologica Congress, Copenhagen, Denmark (1971).

Stout, R.W., Vallance-Owen, J.: Insulin and atheroma. Lancet 1969 I, $1078-1080$.

- Development of vascular lesions in insulin-treated animals fed a normal diet. Brit. med. J. 1970 III, $685-687$.

Volund, A.: Computerized calculation and control of radioimmunoassay or bioassays illustrated for the insulin assay. Paper to be published (1972).

Yalow, R.S., Berson, S. A.: Immunoassay of endogenous plasma insulin in man. J. clin. Invest. 39, 1157-1175 (1960).

Dr. L.G. Heding

Novo Research Institute

115, Fugglebakkevej

2200 Copenhagen- $\mathrm{N}$

Denmark 